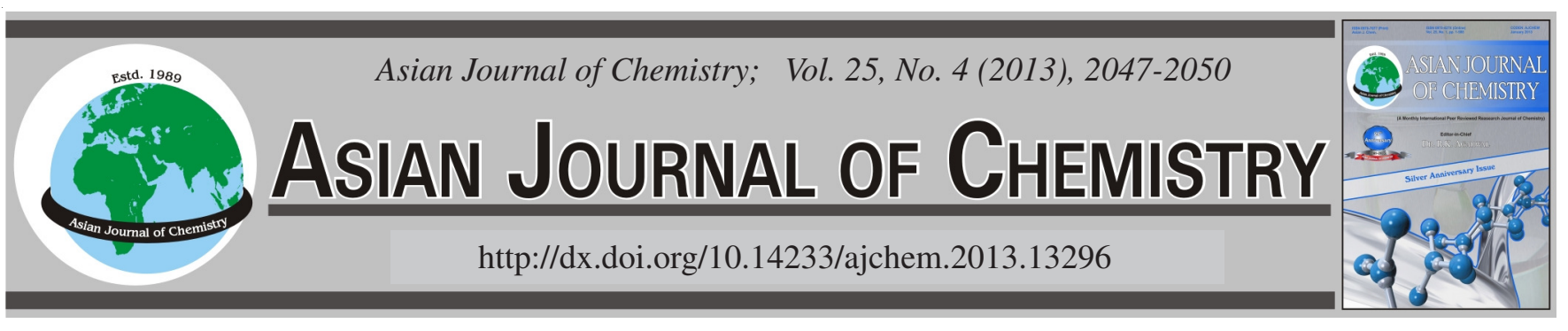

\title{
Effect of Mirtazapine on Gastric Oxidative Stress and DNA Injury Created With Methotrexate in Rats
}

Ismail Demiryilmaz ${ }^{1}$, Hulya Uzkeser ${ }^{2}$, Nihal Cetin $^{3}$, Ahmet Hacimuftuoglu $^{3}$, Ebubekir Bakan $^{4}$ and Durdu Altuner ${ }^{5, *}$

\author{
${ }^{1}$ Department of General Surgery, Private Ibn-i Sina Hospital, Kayseri, Turkey \\ ${ }^{2}$ Department of Physical Therapy and Rehabilitation, Regional Training and Research Hospital, Erzurum, Turkey \\ ${ }^{3}$ Department of Pharmacology, Ataturk University, Erzurum, Turkey \\ ${ }^{4}$ Department of Biochemistry, Ataturk University, Erzurum, Turkey \\ ${ }^{5}$ Department of Pharmacology, Rize University Medical Faculty, Rize, Turkey
}

*Corresponding author: Fax: +90 464 2123015; Tel: +90 464 2123000/3416; E-mail: durdualtuner@ hotmail.com

(Received: 20 December 2011;

Accepted: 12 October 2012)

AJC-12276

\begin{abstract}
In this study, effect of mirtazapine on gastric oxidative stress and DNA injury created with methotrexate was investigated. Experimental results showed that GSH (nmol/g protein), MDA ( $\mu$ mol/g protein) and MPO ( $\mu / \mathrm{g}$ protein) in the gastric tissue of the control group rats receiving methotrexate are $4.97 \pm 0.37,2.78 \pm 0.30$ and $3.12 \pm 0.18$, respectively. GSH, MDA and MPO measurements in the gastric tissue of rats receiving mirtazapine + methotrexate were detected to be $9.23 \pm 0.51(p<0.0001), 1.80 \pm 0.31(p<0.0001)$ and $1.63 \pm 0.25$ $(p<0.0001)$, respectively. GSH, MDA and MPO values in the intact rat group were found $8 \pm 0.38(p<0,0001), 1.63 \pm 0.28(p<0.0001)$ and $1.37 \pm 0.21(p<0.0001)$, respectively. In addition, while 8-ohdG/dG quantity that DNA injury product in the control group administered methotrexate was $2.4 \pm 0.11 \mathrm{pmol} / \mathrm{L}$, this quantity was $1.3 \pm 0.14 \mathrm{pmol} / \mathrm{L}(p<0.001), 1.1 \pm 0.10 \mathrm{pmol} / \mathrm{L}(p<0.001)$ in mirtazapine and intact group, respectively. As a result, it was seen that mirtazapine prevents increase of oxidative stress and DNA injury created with methotreaxete in the gastric tissue of rat.
\end{abstract}

Key Words: Mirtazapine, Methotrexate, Oxidative Stress, DNA Injury, Rat.

\section{INTRODUCTION}

Methotrexate (MTX) is the folic acid antagonist is used for over 40 years in neoplasms, rheumatoid arthritis, psoriasis, leukemias and treatment of some autoimmune diseases ${ }^{1,2}$. It was also found usage area in treatment of sarcoidosis, inflammatory bowel diseases and vasculitis ${ }^{3-5}$. It prevents purine, pyrimidine, deoxyribonucleic acid (DNA) synthesis by inhibition of dihydrofolic acid reductase enzyme and leads to cell injury $^{6}$. Methotrexate inhibits formation of tetrahydrofolate from folic acid. Inhibition of formation of tetrahydrofolate is held responsible for both theurapotic effects and toxic effects of MTX ${ }^{7}$. Cytotoxic effect of MTX is not selective in cancer cells. Therefore, toxicity due to MTX is seen in normal tissues such as hemopoietic system, bone marrow and gastrointestinal system (GIS) mucosa demonstrating high proliferation property. One of the major effects due to MTX is GIS injury ${ }^{8}$. In toxicity studies made with MTX, attention was drawn on oxidative stress. Reactive oxygen products (ROP) play a basic role in GIS injury due to MTX ${ }^{9}$. Suppression of enzymatic and nonenzymatic antioxidant levels, elevation of oxidant levels were shown in GIS, hepatic and renal tissues of experimental animals administered $\mathrm{MTX}^{10}$. Also, they enable occurrence of 8hydroxyguanine (8-OHGua) that DNA injury product by reaction of increased oxygen radicals with $\mathrm{DNA}^{11}$. Therefore, antioxidant treatment is considered to may be useful in prevention or reduction of gastrotoxicity due to methotrexate.

In present study, mirtazapine will use in methotrexate gastrotoxicity is an antidepressant drug used in treatment of depression. In former studies, mirtazapine was demonstrated to suppress production of enzymatic and non-enzymatic oxidant parameters in the gastric tissue, antioxidants were to increase $^{12}$. In literature studies, no information and finding related to mirtazapine's protective effects on gastrotoxicity created with MTX.

In light of all these informations, objective of our study is to observe the mirtazapine's effects on gastric oxidative stress and DNA injury created with methotrexate.

\section{EXPERIMENTAL}

In this study, 30 male albino Wistar rats obtained from medical experimental application and research center of Ataturk university and weighing between 210-220 g were used. 
Animals were housed and fed at normal room temperature $\left(22^{\circ} \mathrm{C}\right)$ in groups before the experiment.

Chemical agents: Thiopental sodium is one of the chemical agents used in the experiment was obtained from I.E. UlagayTurkey, methorexate was from Med-Ilac-Turkey and mirtazapine was from Organon Pharmaceuticals-USA.

Pharmacologic processes: $20 \mathrm{mg} / \mathrm{kg}$ dose of mirtazapine was orally administered in a rat group (n-10) with catheter. Distilled water as solvent was administered in the control group (n-10). After $1 \mathrm{~h}$ of administration of mirtazapine and distilled water, $5 \mathrm{mg} / \mathrm{kg}$ dose of methotrexate was intraperitoneally injected in both groups. This procedure was repeated for 7 days. At the end of this period, all animals were sacrified with high-dose anesthesia and biochemical examinations were performed excising their stomach. Biochemical results obtained from the mirtazapine group were evaluated comparing with results obtained from the control and healthy groups.

\section{Biochemical analyses}

Total GSH determination: The amount of GSH in the tissue was measured according to the method of Sedlak and Lindsay ${ }^{15}$. The tissue surface of the stomach was collected, weighed and then homogenized in $2 \mathrm{~mL} 50 \mathrm{mM}$ Tris- $\mathrm{HCl}$ buffer containing $20 \mathrm{mM}$ EDTA and $0.2 \mathrm{mM}$ sucrose, $\mathrm{pH}$ 7.5. The homogenate was immediately precipitated with $0.1 \mathrm{~mL}$ of $25 \%$ trichloroacetic acid and the precipitate was removed by centrifugation at $4200 \mathrm{rpm}$ for $40 \mathrm{~min}$ at $4{ }^{\circ} \mathrm{C}$. The supernatant was used to determine GSH using 5,5'-dithiobis(2nitrobenzoic acid. Absorbance was measured at $412 \mathrm{~nm}$ using a spectrophotometer.

Determination of MPO activity: MPO activity was measured according to the modified method of Bradley et al. ${ }^{16}$. The homogenized samples were frozen and centrifuged at 1500 $\mathrm{g}$ for $10 \mathrm{~min}$ at $4{ }^{\circ} \mathrm{C}$. MPO activity in the supernatant was determined by adding $100 \mathrm{~mL}$ of the supernatant to $1.9 \mathrm{~mL}$ of $10 \mathrm{mmol} / \mathrm{L}$ phosphate buffer (pH 6.0) and $1 \mathrm{~mL}$ of $1.5 \mathrm{mmol} /$ L $o$-dianisidine hydrochloride containing $0.0005 \%$ (wt/vol) hydrogen peroxide. The changes in absorbance at $450 \mathrm{~nm}$ of each sample were recorded on a UV-VIS spectrophotometer.

Determination of lipid peroxidation or MDA formation: The concentrations of tissue lipid peroxidation were determined by estimating MDA using the thiobarbituric acid test ${ }^{17}$. In brief, the rat stomach were promptly excised and rinsed with cold saline. To minimize the possibility of interference of hemoglobin with free radicals, any blood adhering to the tissue was carefully removed. The tissue was weighed and homogenized in $10 \mathrm{~mL}$ of $100 \mathrm{~g} / \mathrm{L} \mathrm{KCl}$. The homogenate $(0.5 \mathrm{~mL})$ was added to a solution containing $0.2 \mathrm{~mL}$ of $80 \mathrm{~g} / \mathrm{L}$ sodium lauryl sulfate, $1.5 \mathrm{~mL}$ of $200 \mathrm{~g} / \mathrm{L}$ acetic acid, $1.5 \mathrm{~mL}$ of $8 \mathrm{~g} / \mathrm{L} 2$-thiobarbiturate and $0.3 \mathrm{~mL}$ distilled water. The mixture was incubated at $98^{\circ} \mathrm{C}$ for $1 \mathrm{~h}$. Upon cooling, $5 \mathrm{~mL}$ of $n$-butanol:pyridine (15:1) was added. The mixture was vortexed for $1 \mathrm{~min}$ and centrifuged for $0.5 \mathrm{~h}$ at $4000 \mathrm{rpm}$. The absorbance of the supernatant was measured at $532 \mathrm{mn}$.

Isolation of DNA from gastric tissue: Gastric tissue was drawn and DNA isolated using Shigenaga et al.'s modified method $^{19}$. Samples (for stomach tissue $50 \mathrm{mg}$ ) were homogenized at $4{ }^{\circ} \mathrm{C}$ in $1 \mathrm{~mL}$ of homogenization buffer $(0.1 \mathrm{M}$ $\mathrm{NaCl}, 30 \mathrm{mM}$ Tris, pH 8.0, 10 mM EDTA, 10 mM 2-mercapto- ethanol, $0.5 \%$ (v/v) Triton X-100) with 6 passes of a Teflonglass homogenizer at $200 \mathrm{rpm}$. The samples were centrifuged at $4{ }^{\circ} \mathrm{C}$ for $10 \mathrm{~min}$ at $1000 \mathrm{~g}$ to pellet nuclei. The supernatant was discarded and the crude nuclear pellet re-suspended and re-homogenized in $1 \mathrm{ml}$ of extraction buffer $(0.1 \mathrm{M}$ Tris, $\mathrm{pH}$ 8.0, $0.1 \mathrm{M} \mathrm{NaCl}, 20 \mathrm{mM}$ EDTA) and re-centrifuged as above for $2 \mathrm{~min}$. The washed pellet was re-suspended in $300 \mu \mathrm{L}$ of extraction buffer with a wide-orifice $200 \mu$ L Pipetman tip. The re-suspended pellet was subsequently incubated at $65^{\circ} \mathrm{C}$ for $1 \mathrm{~h}$ with the presence of $0.1 \mathrm{~mL}$ of $10 \% \mathrm{SDS}, 40 \mu \mathrm{L}$ proteinase $\mathrm{K}$ and $1.9 \mathrm{~mL}$ leukocyte lysis buffer. Then, ammonium acetate was added to the crude DNA sample to give a final concentration of $2.5 \mathrm{~mol} / \mathrm{L}$ and centrifuged in a micro centrifuge for $5 \mathrm{~min}$. The supernatant was removed and mixed with two volumes of ethanol to precipitate the DNA fraction. After centrifugation, the pellet was dried under reduced pressure and dissolved in sterile water. The absorbance of this fraction was measured at 260 and $280 \mathrm{~nm}$. Purification of DNA was determined as A 260/280 ratio 1.8 .

DNA hydrolysis with formic acid: About $50 \mathrm{mg}$ of DNA was hydrolyzed with $0.5 \mathrm{~mL}$ of formic acid $(60 \%$, v/v) for 45 min at $150{ }^{\circ} \mathrm{C}^{20}$. The tubes were allowed to cool. The contents were then transferred to Pierce micro-vials, covered with Kleenex tissues cut to size (secured in place using a rubber band) and cooled in liquid nitrogen. Formic acid was then removed by freeze-drying. Before analysis by HPLC, they were re-dissolved in the eluent (final volume $200 \mu \mathrm{L}$ ).

Measurement of 8-hydroxy-2 deoxyguanine (8-OH Gua) with HPLC: The amount of $8-\mathrm{OH}$ Gua and guanine (Gua) was measured by using a HPLC system equipped with an electrochemical detector (HP Agilent 1100 module series, E.C.D. HP 1049 A), as described previously ${ }^{20,21}$. The amount of 8-OH Gua and Gua was analyzed on a $250 \mathrm{~mm} \times 4.6 \mathrm{~mm}$ Supelco LC-18-S reverse-phase column. The mobile phase was $50 \mathrm{mM}$ potassium phosphate, $\mathrm{pH}$ 5.5, with acetonitrile (97 volume acetonitrile and 3 volume potassium phosphate) and the flow rate was $1.0 \mathrm{~mL} / \mathrm{min}$. The detector potential was set at $0.80 \mathrm{~V}$ for measuring the oxidized base. Gua and $8-\mathrm{OH}$ Gua (25 pmol) were used as standards. The 8-OH Gua levels were expressed as the number of $8-\mathrm{OH}$ Gua molecules/105 Gua molecules ${ }^{22}$.

Statistical analysis: All data were analyzed by one-way ANOVA using SPSS 13.0 software. Differences among groups were obtained using the LSD option and Duncan test and significance was declared at $p<0.05$.

\section{RESULTS AND DISCUSSION}

As seen from Table-1 and Fig. 1, GSH, MDA and MPO in the gastric tissue of the group rats receiving methotrexate measure $4.97 \pm 0.37 \mathrm{nmol} / \mathrm{g}$ protein, $2.78 \pm 0.30 \mu \mathrm{mol} / \mathrm{g}$ protein and $3.12 \pm 0.18 \mu / \mathrm{g}$ protein, respectively. GSH, MDA and MPO measurements in the gastric tissue of rats receiving mirtazapine + methotrexate were to be $9.23 \pm 0.51(p<0.0001)$ $\mathrm{nmol} / \mathrm{g}$ protein, $1.80 \pm 0.31(p<0.0001) \mu \mathrm{mol} / \mathrm{g}$ protein and $1.63 \pm 0.25(p<0.0001 \mu / \mathrm{g})$ protein, respectively (Fig. 2). GSH, MDA and MPO values in the intact rat group were found $8 \pm 0.38(p<0.0001) \mathrm{nmol} / \mathrm{g}$ protein, $1.63 \pm 0.28(p<0.0001)$ $\mu \mathrm{mol} / \mathrm{g}$ protein and $1.37 \pm 0.21(p<0.0001) \mu / \mathrm{g}$ protein, respectively (Fig. 3). 


\begin{tabular}{lccccccc}
\hline \multicolumn{7}{c}{ TABLE-1 } \\
OXIDATIVE PARAMETERS IN RAT GROUPS \\
\hline
\end{tabular}

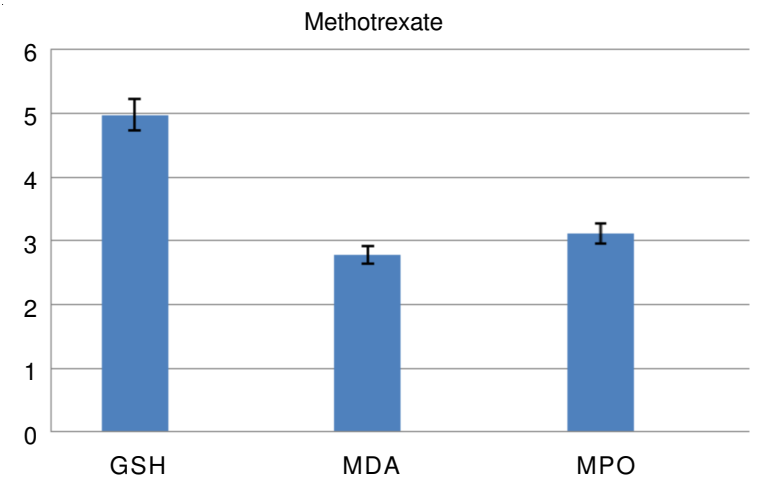

Fig. 1. GSH, MDA and MPO levels in methorexate administered rat group

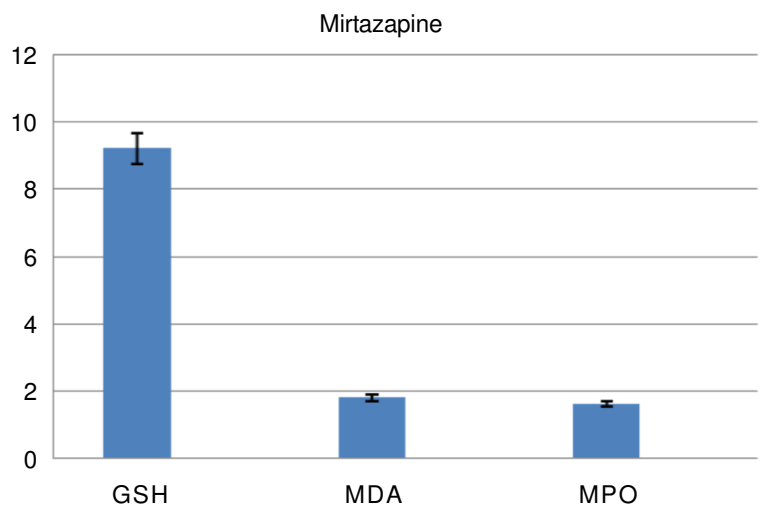

Fig. 2. GSH, MDA and MPO levels in mirtazapine administered rat group

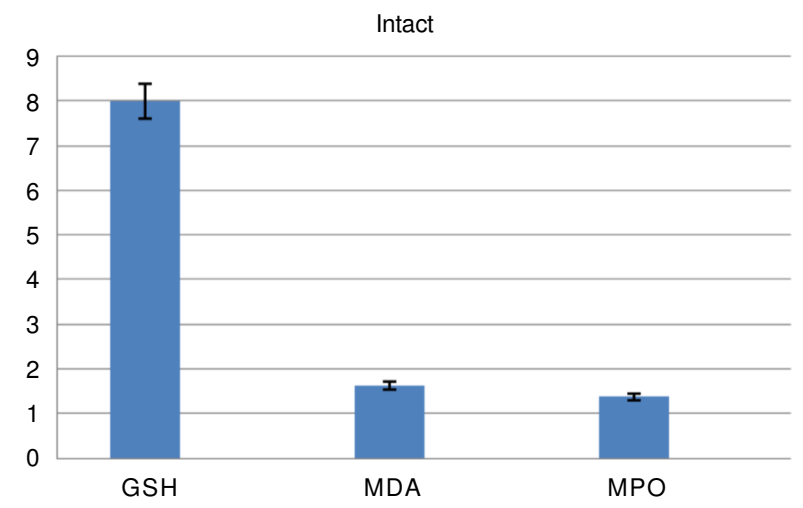

Fig. 3. GSH, MDA and MPO levels in intact rat group

While 8-OHGua quantity in the control group administered methotrexate was $2.4 \pm 0.11 \mathrm{pmol} / \mathrm{L}$, this quantity was $1.3 \pm 0.14 \mathrm{pmol} / \mathrm{L}(p<0.001), 1.1 \pm 0.10 \mathrm{pmol} / \mathrm{L}(p<0.001)$ in mirtazapine and healthy animal groups, respectively (Fig. 4).

In this study, effect of mirtazapine on gastric oxidative stress created with methotrexate was biochemically investigated in rats. The results demonstrated that there is significant elevation in quantities of oxidant parameters such as MDA,

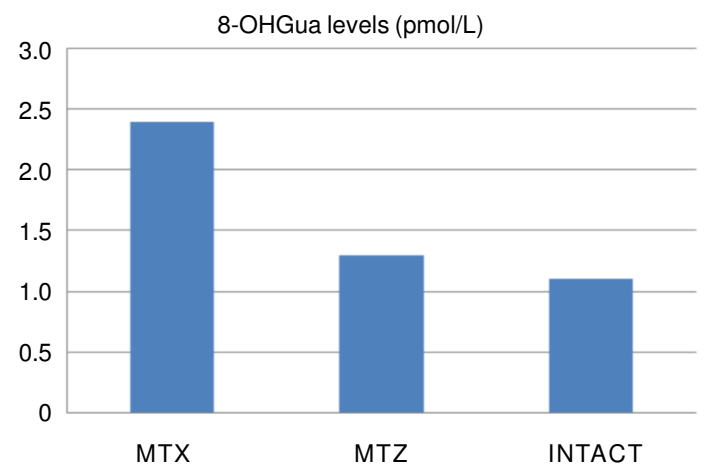

Fig. 4. 8-OHGua levels in rat groups

MPO and reduction in quantity of GSH that antioxidant parameter in the gastric tissue of the control group rats receiving MTX. Methotrexate administration in rats was found to decrease GSH levels and to increase MPO activity that indicator of inflammatory response and MDA levels that indicator of lipid peroxidation in blood, liver, kidney and small bowel ${ }^{10}$. Celebi et $a l .{ }^{13}$ also showed that GSH quantity is low in the injured gastric tissue. Miyazono et al. ${ }^{14}$ demonstrated that adverse effect of MTX on digestive system arises from GSH reduction and propounded that oxidative stress has an important role in injury caused by MTX. Ozbakis et al. ${ }^{15}$ also showed that there is a reduction in quantity of GSH in the injured gastric tissue. These literature informations reveal that they are in concordance with our experiment results. As known, gluthation is an important parameter used in measurement of oxidative stress. GSH is a tripeptide which can be synthesized from glutamate, cysteine and glycine in liver. GSH, a very important antioxidant, reacts with free radicals and peroxides and protects cells against oxidative injury by converting them to harmless products. It makes this effect by holding sulfhydryl groups in proteins reducedly ${ }^{16}$.

In present study, significant elevation in quantity of MDA was seen in the gastric tissue of the control group administered MTX. In another study, significant elevation in quantity of MDA, reduction in quantity of gluthation in bowel injury created with MTX were reported ${ }^{17}$. Again in another study, MDA quantity in the injured gastric tissue was found to be high in proportion to the non-injured tissue ${ }^{18}$. MDA is the final product of lipid peroxidation and is a dialdehyde occurring by division of peroxidized poly-unsaturated fatty acids. MDA is commonly uses as an indicator of oxidative state. MDA over-produced in consequence of lipid peroxidation causes severe injury in cells ${ }^{19}$. This injury occurring via lipid peroxidation is irreversible ${ }^{20}$.

In present study, the significant augmentation in MPO activity was also detected in animal liver receiving MTX.

MPO is a marker of neutrophil infiltration. Free radicals cause more exacerbation of tissue injury over active neutrophils 
by enabling collection of leukocytes in the injured tissue ${ }^{21}$. When phagocytic leukocytes are stimulated, they increase oxygen consumption. This event is called as respiratory/ oxidative burst. Active neutrophils secrete MPO and reveal oxygen radicals ${ }^{22}$. In experimental studies on rats, MTX was identified to increase MPO activity that marker of neutrophil infiltration ${ }^{10}$. Studies indicating augmentation of MPO activity in the injured gastric tissue were found ${ }^{23,24}$.

Free oxygen radicals cause severe injury not only on lipids also on DNA. Free oxygen radicals lead to emergence 8hydroxyguanine (8-OHGua) that mutagenic, by reaction with DNA $^{11,25}$. As seen from present results, 8-OHGua quantity was also found high in the gastric tissue where MDA is found high. These results indicate that MTX leads oxidative injury in the gastric tissue and causes severe injury also on DNA. In addition, 8-OHGua quantity was identified to increase in parallel with raise of MPO activity. As stated above, active neutrophils secrete MPO and emergence oxygen radicals. Hydrogen peroxide arising from activated neutrophils leads DNA injury, cell dysfunction and even cell death, by passing easily through membranes and arriving at cell nucleus ${ }^{26}$. Owing to the fact that 8-OHGua is labile in DNA structure, it is spontaneously depurinised and causes a basic areas ${ }^{27}$.

Free oxygen radicals cause injury on deoxyribose phospate skeleton in DNA structure, specific modification of purine and pyrimidine bases and formation of DNA-protein cross links ${ }^{28,29}$. While oxidation of deoxyribose skeleton induces base release and DNA chain fractures, oxidative base modifications lead mutation ${ }^{30,31}$. The one that most occurs within DNA products and that is mutagenic is $8-\mathrm{OHGua}^{32}$. 8-OHGua found in DNA structure is known to lead $\mathrm{G} \Xi \mathrm{C} \rightarrow$ $\mathrm{T}=\mathrm{A}_{\text {mutation }}^{30,33}$.

\section{Conclusion}

In present study, lower being found of quantities of MDA, MPO and 8-OHGua in animal groups receiving mirtazapine in proportion to the control group and higher being found of GSH show that MTX suppresses oxidative DNA injury created in the gastric tissue. As known, mirtazapine is an antidepressant drug. As well as antidepressant property of mirtazapine, it also has antioxidant, antiulcer properties and property of blocking 5-HT2 and 5-HT3 receptors ${ }^{12,34}$. Mirtazapine's this protective effect on MTX gastrotoxicity may be considered to have proceeded from its property to be both antioxidant and serotonin receptor antagonist. Stimulation of these 5-HT2 and 5-HT3 receptors in tissues was reported to be associated with toxic adverse effects ${ }^{34}$. As a conclusion, mirtazapine was seen to prevent augmentation of oxidative stress and DNA injury created with methotrexate in the gastric tissue of rats.

\section{REFERENCES}

1. R.L. Schilsky, Stem Cells, 14, 29 (1996).

2. L. Naldi and C.E. Griffiths, Br J. Dermatol., 152, 597 (2005).

3. J.J. Wu and K.R. Schiff, Am. Fam. Physician, 70, 312 (2004).

4. B.G. Feagan and A. Alfadhli, Gastroenterol Clin. North Am., 33, 407 (2004).

5. C.A. Langford, Best Pract. Res. Clin. Rheumatol., 15, 281 (2001).

6. H. Friis and P.B. Andreasen, J. Int. Med., 232, 133 (1992).

7. J. Jolivet, K.H. Cowan, G.A. Curt, N.J. Clendeninn and B.A. Chabner, N. Engl. J. Med., 309, 1094 (1983).

8. J. Nagakubo, T. Tomimatsu, M. Kitajima, H. Takayama, N. Aimi and T. Horie, Life Sci., 69, 739 (2001).

9. F. Gao and T. Horie, Life Sci., 71, 1091 (2002).

10. N. Jahovic, H. Cevik, A.O. Sehirli, B.C. Yegen and G. Sener, J. Pineal Res., 34, 282 (2003).

11. L.J. Marnett, Carcinogenesis, 21, 361 (2000).

12. M. Bilici, C. Ozturk, H. Dursun, F. Albayrak, M.B. Saglam, A. Uyanik, M. Gulaboglu and S.B. Tekin, Dig. Dis. Sci., 54, 1868 (2009).

13. F. Celebi, A. Akbas, M.B. Saglam, A. Kisaoglu and H.H. Alp, Asian J. Chem., 24, 1966 (2012).

14. Y. Miyazono, F. Gao and T. Horie, Scand. J. Gastroenterol., 39, 1119 (2004).

15. G.O. Dengiz, F. Odabasoglu, Z. Halici, E. Cadirci and H. Suleyman, J. Pharmacol. Sci., 105, 94 (2007).

16. M.L. Urso and P.M. Clarkson, Toxicology, 189, 41 (2003).

17. T.T. Jubeh, S. Antler, S. Haupt, Y. Barenholz and A. Rubinstein, Mol. Pharm., 2, 2 (2005).

18. B. Polat, Y. Albayrak, B. Suleyman, H. Dursun, F. Odabasoglu, M. Yigiter, Z. Halici and H. Suleyman, Pharmacol. Rep., 63, 518 (2011).

19. G. Cighetti, L. Duca, L. Bortone, S. Sala, I. Nava, G. Fiorelli and M.D. Cappellini, Eur. J. Clin. Invest., 32, 55 (2002).

20. J.M.C. Gutteridge, Clin. Chem., 41, 1819 (1995).

21. N.D. Vaziri, Semin. Nephrol., 24, 469 (2004).

22. G.W. Sullivan, I.J. Sarembock and J. Linden, J. Leukoc. Biol., 67, 591 (2000).

23. A. Kisaoglu, B. Ozogul N. Cetyn, B. Suleyman, S.S. Atamanalp, F. Akcay and H. Suleyman, Int. J. Pharmacol., 7, 682 (2011).

24. E. Cadirci, H. Suleyman, H. Aksoy, Z. Halici, U. Ozgen, A. Koc, N. Ozturk, Chem.-Biol. Interact., 170, 40 (2007).

25. H.Y. Huang, K.J. Helzlsouer and L.J. Appel, Cancer Epidem. Biomar., 9, 647 (2000).

26. A.M. Knaapen, N. Güngör, R.P.F. Schins, P.J.A. Brom and F.J.V. Schooten, Mutagenesis, 21, 225 (2006).

27. A.E. Aust and J.F. Eveleigh, Proc. Soc. Exp. Biol. Med., 222, 246 (1999).

28. M. Dizdaroglu, Free Radic. Biol. Med., 10, 225 (1991).

29. M.K. Shigenaga and B.N. Ames, Free radic. Biol Med., 10, 211 (1991).

30. K.C. Cheng, D.S. Cahill, H. Kasai, S. Nishimura and L.A. Loeb, J. Biol. Chem., 267, 166 (1992).

31. Y. Kuchino, F. Mori, H. Kasai, H. Inoue, S. Iwai, K. Miura, E. Ohtsuka and S. Nishimura, Nature, 327, 77 (1987).

32. M.K. Shigenaga, C.J. Gimeno and B.N. Ames, Proc. Nat. Acad. Sci., 86, 9697 (1989).

33. A.R. Collins, S.J. Duthie, L. Fillion, C.M. Gedik, N. Vaughan and S.G. Wood, Biochem. Soc. Trans., 25, 326 (1997).

34. A. Frazer, Depression, 2, 1 (1994). 